
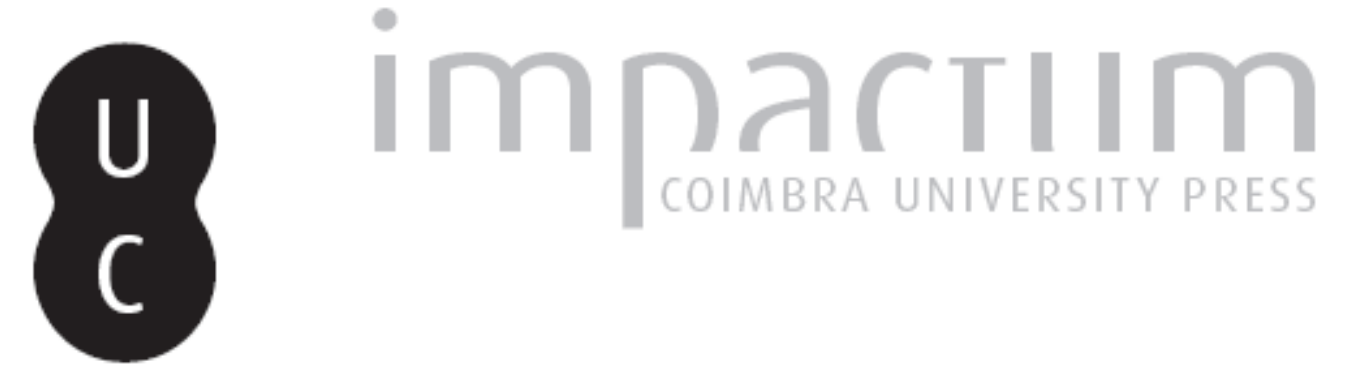

\title{
Polycentrism in a post-hegemonic world and the future of the European Union
}

Autor(es): $\quad$ Valente, Isabel Maria Freitas; Freire, Maria Raquel; Fernandes, Sandra

Publicado por: Centro de Informac̃ão Europe Direct de Aveiro; Centro de Estudos

URL

persistente:

URI:http://hdl.handle.net/10316.2/40944

DOI:

DOI:https://doi.org/10.14195/1647-6336_15-1_5

Accessed : $\quad$ 26-Apr-2023 15:05:16

A navegação consulta e descarregamento dos títulos inseridos nas Bibliotecas Digitais UC Digitalis, UC Pombalina e UC Impactum, pressupõem a aceitação plena e sem reservas dos Termos e Condições de Uso destas Bibliotecas Digitais, disponíveis em https://digitalis.uc.pt/pt-pt/termos.

Conforme exposto nos referidos Termos e Condições de Uso, o descarregamento de títulos de acesso restrito requer uma licença válida de autorização devendo o utilizador aceder ao(s) documento(s) a partir de um endereço de IP da instituição detentora da supramencionada licença.

Ao utilizador é apenas permitido o descarregamento para uso pessoal, pelo que o emprego do(s) título(s) descarregado(s) para outro fim, designadamente comercial, carece de autorização do respetivo autor ou editor da obra.

Na medida em que todas as obras da UC Digitalis se encontram protegidas pelo Código do Direito de Autor e Direitos Conexos e demais legislação aplicável, toda a cópia, parcial ou total, deste documento, nos casos em que é legalmente admitida, deverá conter ou fazer-se acompanhar por este aviso. 
DEBATER

A EUROPA

Supplementum

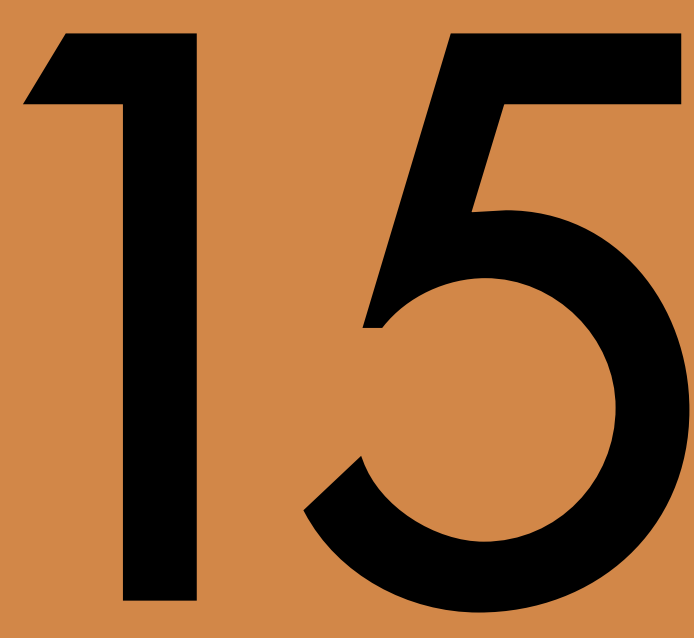

jul-dez 2016

GLOBAL TRENDS 2030:

THE FUTURES OF PORTUGAL

IN AND BEYOND EUROPE 


\title{
Polycentrism in a post-hegemonic world and the future of the European Union
}

\author{
Isabel Maria Freitas Valente, $\mathrm{PhD}$ \\ Centre of 20th Century Interdisciplinary Studies of the University of Coimbra - CEIS20 \\ E-mail: valente.isa@gmail.com
}

Maria Raquel Freire, $\mathrm{PhD}$

School of Economics of the University of Coimbra

E-mail: rfreire@fe.uc.pt

Sandra Fernandes, $\mathrm{PhD}$

University of Minho

E-mail: sfernandes@eeg.uminho.pt

This report* reflects the main issues faced by the international system and the challenges that it entails, in view of the dynamism of the international relations and the new multipolar or polycentric configurations that characterise such system. The report is based on the Serralves conferences (2016) dedicated to the topic 2030 Global Trends: The Futures of Portugal, scientifically coordinated by Álvaro de Vasconcelos, on the European Union reports 2030 Global Trends: Can the EU meet the challenges ahead? ${ }^{1}$, and on the Global trends 2030: Alternative worlds by the National Intelligence Council. ${ }^{2}$ One of the main guidelines that is repeatedly present throughout the Serralves Conferences was the polycentric and post-hegemonic trend in the international relations

\footnotetext{
* This report is the result of the work of the Group consisting of Elena Brugioni, Isabel Maria Freitas Valente, João Figueiredo, Jorge Tavares da Silva, Maria Raquel Freire and Sandra Fernandes.

1 "Global Trends to 2030: Can the EU meet the challenges ahead?", ESPAS - European strategy and policy analysis system. Luxembourg: Publications Office of the European Union, 2015. Available at: http://europa.eu/espas/pdf/espas-report-2015.pdf.

${ }^{2}$ National Intelligence Council, "Global Trends 2030: Alternative worlds". December 2012. Available at: https://globaltrends2030.files.wordpress.com/2012/11/global-trends-2030-november2012.pdf.
} 
field. In the opening session, Álvaro de Vasconcelos mentioned that the distribution of power around the globe points to a polycentric world, where a multiplicity of actors takes on increasing importance. He added that in this multi-polar scene, medium powers will probably play a greater part, which will inevitably have an impact on the role and position of the European Union (EU) within the international system. In the same vein, Braga da Cruz drew attention to the danger of an unprepared and dormant EU, essentially reactive in its responses to the numerous challenges of our time. In his turn, as a complement to the previous presentations, Pedro Dallari highlighted the duality in the international politics domain between a setting of fragmentation, in which there are no clearly identified centres of gravity with specific management functions, and a scenario where convergences, uniformity, and even harmony are created - the ideal context for the intervention of international law. ${ }^{3}$ Thus, the present work takes as lines of analysis the issues of polycentrism and the convergence/fragmentation in the international system, with particular focus on the EU and the Portuguese case. Therefore, the following relevant questions can be asked: What governance? What is the meaning of it? Is it an alternative to neoliberalism as a model of world governance, led by the Western powers? What are the implications of a changing order for Portugal?

\section{Post-hegemonic polycentrism: a historical and political introduction}

Historically, the roots of a polycentric and post-hegemonic scenario can be found in the rubble of World War II, when under the atomic clouds of Hiroshima and Nagasaki (1945) emerged a new international order, with clear contours and based on the sharing of power between two major global powers: the United States of America (USA) and the Soviet Union. Their certain ability to totally annihilate one another kept the two blocks in a position of balance, which up to that date was only apparently stable, yet depending on countless "proxy wars" and the maintenance of a vague climate of terror. With the surprising fall of the Berlin Wall in 1989, not only did the various authoritarian regimes of the East collapsed, thick and fast, as the Western liberal democracies also triumphed, led by the USA and under the protecting mantle of the Atlantic Alliance. The bipolar system hence gives place to a unipolar hegemony that, in a climate of reigning optimism, is understood as durable in triumphalist readings of the "end of History". A cycle of rapid erosion of this international planning begins almost

\footnotetext{
3 “Convergence in an interconnected world or fragmentation?", conference report, September 28, 2015.

${ }^{4}$ Fukuyama, Francis (1999) O Fim da História e o Último Homem. Lisbon: Gradiva.
} 
immediately, symbolically marked by the Yugoslav Wars (1991-2001), reaching an important milestone with the invasion of Iraq (2003), and culminating in the 2008 financial and economic crisis. The solid unipolar system is then relegated to the past.

In this context, in the session "World Governance in a Polycentric World: The Perspective of the Emerging Powers", Nuno Severiano Teixeira (moderator) and Álvaro de Vasconcelos (commissioner) portrayed the present global conjuncture as deeply marked by the end of global hegemonies and a diffusely multipolar polycentrism. This diffusion of power was one of the megatrends identified by the report Global Trends 2030: Alternative Worlds (2012) by the National Intelligence Council, whereas, in turn, the study Citizens in an Interconnected and Polycentric World: Global Trends 2030 (2011) by the European Union Institute for Security Studies had indicated that the coming decades would be marked not only by a post-hegemonic polycentrism and a multipolar arrangement of the world system, but also by a striking gravitation of the decision centres towards the Asian context at a regional level.

As Nuno Severiano Teixeira stated, at the present time, several guidelines lead the international relations in a global context characterised by the emergence of geographically scattered centres, which provide the basis for actors of diverse nature and dimension: from state powers of different extent and historical consolidation (e.g. small, medium and large powers) to non-state actors (e.g. cities, non-governmental organisations, various interest groups), private or public multinationals, and crossborder networks (such as terrorist organisations). How to combine the two major and sometimes contradictory dynamics that define this panorama: the 'Westphalian', which relates to the future of the states; and the global, marked by these transnational trends that are more diffuse and yet no less decisive? According to Radha Kumar and João Gomes Cravinho (who spoke at the aforementioned session), the answer to this dilemma varies according to the point of view of the speakers in the international relations field. The most consolidated states, the great historical, military or economic powers, tend to follow a much more conservative logic than the new emerging actors, who act with revisionist objectives, i.e. amending the rules that guide the international order.

The EU faces additional challenges arising from the sui generis and intrinsically innovative nature of this political formation, which includes both the states increasingly consolidating as medium actors in the global scene, and others that seem to be doomed to a position of peripheral subalternity, if not within the EU, in the global economic, 
political, or cultural stages. In the present context, characterised by multipolarity, polycentrism, and the diffusion of power at various scales, it is not at all clear how a stable equilibrium may be reached. As Álvaro de Vasconcelos observed in his presentation "Convergence in an interconnected world or fragmentation?", and in accordance with Mathew J. Burrows' speech at the session on "Economic Trends in a Polycentric World: Social Justice and Governance, or Globalisation at Risk?", the transitory nature of the current situation forces analysts to admit the likely emergence of radically new and inherently unpredictable scenarios. The outlining of scenarios and approval of strategies, although contingent, are effective ways to ensure national change, which is as dependent on an internally determined course as on the international context.

\section{Scenarios and strategies in a polycentric context}

The fundamental changes that have occurred in the international system - defined as tending towards polycentrism and post-hegemony - lead us to identify some possible lines of thinking: the position of the EU regarding this topic; issues relating to European security and defence; the importance of the Portuguese language as a factor of empowerment; and potential scenarios/roles for Portugal and the EU in such a background.

\subsection{The European Union in a polycentric world}

As the central unit of the international 'Westphalian' system, the state has been losing centrality in the face of the emergence and consolidation of new actors, from non-governmental organisations and non-territorial terrorist groups to multinational companies and informal networks in various areas. These new political formations of diverse nature defy the status quo, either in a logic of complementarity and cooperation regarding the international order based on state power, or in a destabilising and dissenting perspective. Such an evolution leads inevitably to situations of "absence of governance" ${ }^{, 5}$, when the mechanisms that previously coordinated and constricted the relations between states are unable to provide answers to the new realities that arise through the meshes of the 'Westphalian' system. Imminent examples of this kind of systemic failures emerge every day from the Mediterranean, North Africa, and in

\footnotetext{
${ }^{5}$ Citizens in an Interconnected and Polycentric World. Global Trends 2030. Paris: EUISS. Available at: http://europa.eu/espas/pdf/espas_report_ii_01_en.pdf.
} 
particular the Middle East, as testified by António Guterres at the conference "The tragedy of the refugees and the international response", as well as by Mustapha Ben Jafar and Francisco Seixas da Costa in the session dedicated to the theme "Case Study: The Southern Mediterranean Between Democracy and War".

The decentralisation of the state as a 'basic unit' to consider while studying international relations or global geopolitics, however, does not entail its entire collapse, but only its horizontal coexistence with other entities, giving rise to a system of variable geometry not extendable in the same way and scale to all parts of the globe. It is not, therefore, a paradox that, at the same time, we are able to witness the growing effect of populist movements and centralised drifts in search of a strong and integralist national authority, depicted as capable of guaranteeing the traditional principle of sovereignty and the immediate physical safety of citizens. In a context where new technologies have given citizens more information and some empowerment, they are still easily manipulated, as Janine Ribeiro and Guilherme d'Oliveira Martins advised at the conference "What is the Future of Democracy and Citizens' Demands?". It is also worth referring the border closure, as well as the retrogression in free movement, and the events of the so-called 'Arab Springs' as examples of such effect.

If we complexify this reality, it is possible to verify the coexistence of emerging state powers like Brazil, China, and India, which aim to strengthen their power in such a way that they directly echo the 'Westphalian' principles, although they are 'revisionists' in terms of regional geopolitical balance. The rising of state centralism based on nationalist assumptions, and of identity, or even openly xenophobic or islamophobic integralisms is also a reality within the EU. The same phenomenon can be observed in contexts of 'governance absences' or peripheral 'ghettos', and constitutes a possible path for rising regional power states, such as South Africa, Indonesia, and Turkey, or declining ones, as is the case of Russia and Japan.

However, despite our awareness of these trends, this does not mean that the state has lost importance in the international system. In fact, the challenges faced by the state are multiple and have generated adverse effects of both diffusion and centralisation of power. Let us take, for instance, the case of transnational terrorism and the centralising effect in search of a national authority that can ensure the traditional principle of sovereignty and the security of citizens, which has become a tendency in the international system. The closing of borders, the retrogression in free movement, and the greatest internal and external controls under state authority are good examples. 
Therefore, the challenges to a state-centred order do exist, but remain limited. A multilevel analysis shows that this very complexity is inherent to the power configurations distinguished within the EU, where the differences between member states reflect the integration process from the start, but have taken on more rigid contours in the context of volatility we are and will be experiencing in the coming years. Paradoxically, the EU intended to become a pioneering form of government, free from the traps inherent to a state, although that has never been attained. In this sense, the challenges to the integration process are manifold.

\subsubsection{Implications for the $E U$}

In such a background, three scenarios have been forecast:

1) the deepening of the European integration following a federalist model, in which member states grant greater powers to the community instead of to the intergovernmental dimension. This is an 'old dream' of the European federalists and an ideal still to achieve, but one that in the face of several external challenges may assume a new dimension in the next decades;

2) the collapse of the EU due to the inability to maintain binding and cohesion building policies. This is a pessimistic scenario in which all the political, economic, social, and cultural investment that allowed the process of integration to take place and shape thins out in struggles for power and influence, nationalist speeches, and a potential return to scenes of violence scenarios. To this reflection adds the issue of the impact of the EU's dissolution not only for its member states but also regarding the strategic partnerships planned, preferential agreements established, and a series of global cooperation practices already rooted;

3) and the EU at various speeds, where the dynamics of integration are implemented heterogeneously, in accordance with different wishes, more or less committed to the project of the EU, at political, economic, security, or defence levels. On the one hand, this scenario, which currently seems to be gathering speed, warns about national differentials in terms of perspectives for European integration, while stressing the existing differential, which has gained relevance in the European scene. These several scenarios offer different readings on the future of the EU, revealing the challenges faced and the options available, with implications for Portugal. 


\subsubsection{Implications for Portugal}

As we all know - although we can never stress it enough -, when Portugal formally joined the European communities along with Spain, in 1986, a new geopolitical dimension was given to the process of European construction. The European Community thereby acquired a privileged presence in the Atlantic - the space of confluence between the European, American and African continents, through the autonomous regions of the Azores and Madeira, as well as the Canary Islands Autonomous Community. In the context of globalisation, the EU is the only continental area that can assert its legitimate presence either in the Atlantic, Mediterranean, and North Sea, or in the Indian Ocean, the Caribbean and the South American seas, exactly through the outermost regions, whose good relations with neighbouring countries can provide more direct cooperation ties with various regional contexts, while overcoming the simple logic of a unidirectional and hierarchical North-South cooperation.

In fact, this geopolitical legacy provides valuable bridges between the EU and the several African states, the MERCOSUR, and the United States of America, extending the maritime dimension of the EU and thus contributing to its neighbourhood and cooperation policy. In this context, it should also be noted that the outermost regions share an environment of cooperation enshrined in the Cotonou Agreement with the various African, Caribbean, and Pacific states that signed the Lomé Convention (ACP countries) and with the Overseas Countries and Territories (OCTs). As Janine Ribeiro emphasised in the session "What is the Future of Democracy and Citizens' Demands?", such an environment of cooperation should invariably start being based not only on improving the levels of well-being and the access to minimum economic conditions, but also on the common and effective expression of such universal values as peace, participatory democracy, and respect for fundamental and human rights. In this context, the Portuguese island regions, as stages of secular heritage crossings, can increasingly become the "active frontiers of the European Union in the world". Through them, Portugal may play an essential role in redefining the European global presence. This same idea was highlighted by Durão Barroso, as he stated in the session "World Governance in a Polycentric World: EU challenges" that Portugal lies at the centre and not in the fringes of the globalised world. In the same line of thought, Adelino Maltez holds that Europe should join the Atlantic vision of Portugal - "the North Atlantic and 
the Atlantic Creole ones, and the one that allowed Europe to travel to the East, China, and the Pacific. Something more universal than the Rhenish troubles of little Europe". ${ }^{6}$

A collapsing European project takes on disturbing contours in terms of an impact for Portugal, given its dependence on European structures at different sectoral levels. The integration of Portugal in the EU remains an option without choice. The small size of such Medieval Kingdom (which remains the same until today) determined that the continuity of the Portuguese project of political unity could only be achieved by going "D’Áquem para D’Álém Mar" (from here to beyond the sea), in Zurara's words. In this sense, the European project is our new "D'Álém" (beyond the sea) since we lost our colonies.

If on the one hand the federalist scenario translates into a possible further integration of Portugal within the structures, on the other hand, it can also represent a reduced power of negotiation and influence within these structures. However, this trend seems to demonstrate an agreement on the perspective that a federal step within the EU would be favourable to Portugal, and would allow it to increase its influence. Against the backdrop of a multi-speed Europe, Portugal remains at the forefront of the major issues, including on security matters - an idea supported by Barroso in his speech. However, it is important to stress that the capacities do not always match the will, which means that Portugal does not/will not always have the means to fully participate in some decisions, especially on defence matters, just like the other member states. This strategy of involvement and participation has, nonetheless, defined Portugal's attitude and, in the long term, seems to serve national interests, even within material constraints.

The discussion on how the process of European integration has made/can make Portugal a peripheral country is very relevant in this context. Today, periphery and centrality are dynamic and broad concepts that are not restricted to geography, but also have political, economic, and social dimensions. If, after joining the EEC, as mentioned, Portugal benefited from a clear centrality while bringing closer various oceans, this same centrality has been questioned by an essentially economic peripherisation. The financial and economic crisis affecting the country and rendering it more dependent on both European and global financial structures, is contributing to reduce its status within the European institutional framework. In 2030, Portugal may find new paths of recentralisation of its position in Europe and abandon its peripheral status. This path

\footnotetext{
${ }^{6}$ See: It was not Portugal that joined the EEC, but the European Union who has not yet joined our 'armillary hug'. Available at: http://forteapache.blogs.sapo.pt/298904.html
} 
must be pursued by building new options in the Atlanticist and southern country speeches, based on privileged dialogues with a more proactive mediation role, for example, in Africa, a territory that has registered a remarkable growth and development over the last decades, as Carlos Lopes argued in the session on "Economic Trends in a Polycentric World: Social Justice and Governance or Globalisation at Risk?”.

As a small state without delicate compromises in the international system beyond the alignment with the EU, when the latter assumes a position of consensus as to external matters, Portugal is well placed in this regard. On the other hand, Portugal can maintain its increasingly peripheral status of Southern EU country, where a fragile economic situation, along with the consequent policy implications resulting therefrom, will eventually prevent its overcoming a state of marginalisation, which will relegate its influence and capacity for action in the EU to a peripheral level.

\subsection{Implications in/to security and defence within the context of the Atlantic Alliance}

The Atlantic Alliance (NATO) and the EU can provide a framework of security and stable deterrence, which has been achieved, for instance, with the management of the status quo created by the Ukrainian crisis towards Russia. However, there are a number of transnational dynamics and phenomena posing threats to Portugal to which the aforementioned institutional frameworks cannot immediately respond. To begin with, there is a close relationship between security and defence due to the evolution of the internal political environment, which has been very much limited by the lack of financial resources. Social imbalances, unemployment, and the difficulties in terms of well-being are factors of social pressure that foster insecurity. As Guilherme d'Oliveira Martins stressed, the emerging social movements in a context of crisis - anarchic and urban insurgency groups - tend to proliferate when the national economic indicators are unstable, posing some of the times a populist threat to a representative and constitutional democracy.

Some of the threats to the regional bloc are also threats to Portugal. The instability in their neighbourhoods is particularly worrying in North Africa and the Middle East with a direct social and economic impact in Western Europe due to large scale migrations - as well as the insecurity resulting from the entry of illegals and the spread of organised crime, piracy, and the strengthening of international terrorism associated with jihadism. The pressures on Europe's Schengen border can lead to two antinomic 
reformulation trends: an improvement towards effectiveness or the gradual dismantling as a result of national and protectionist decisions of individual member states. This idea was mirrored by Álvaro de Vasconcelos at the session on "Case Study: The Southern Mediterranean between Democracy and War" in the argument that the Southern Mediterranean entails a fundamental dichotomy between convergence and fragmentation.

The instability in the Eastern neighbourhoods also raises serious security challenges due to the memorable failure of the EU's model of political and economic approach to the countries of the post-Soviet territory, in particular, Russia. In this context, in the eyes of certain EU member states, the securitisation of Russia will place the emphasis on strengthening the Atlantic Alliance as a safeguard of European security. With strong Euro-Atlantic interests, Portugal might choose to strengthen its participation in this organisation towards greater proactivity ('burden sharing') in the same line of what the American leadership defends in its new 'leading from behind' doctrine.

In the light of what has been said and in line with the EU's report Global Trends to 2030, we can infer the following:

It is likely that in 2030 NATO and the United States will remain the provider of last resort for European Union security. Defence and military operations will likely increasingly be operated by coalitions, as European Union Member States may not have the capacity to carry them out alone. (p.73)

\subsection{Possible implications for the Portuguese language}

The presentation of Carlos Lopes and Mathew J. Burrows in the conference on the theme "Economic Trends in a Polycentric World" leads us to conclude that the Portuguese-speaking countries can be found in different regional contexts, particularly in South America and Sub-Saharan Africa, with diverse perspectives of economic growth and social development, and that the Portuguese language is a heritage that must be cultivated and valued. In quantitative terms, it is interesting to consider the data regarding the number of speakers of Portuguese, a language shared by 240 to 245 million people, including those who have it as a mother tongue, second language, or foreign language, as well as its polycentric and transnational dimension; Portuguese is also the official language of eight countries in five continents and several governmental and intergovernmental organisations. If we add information on the role Portuguese 
language plays in global media, as well as on its importance in the Internet and social networks - where it ranks among the five most used languages, according to the Internet World Stats, ${ }^{7}$ it is easy to explain the economic, cultural, and social potential of this rich linguistic heritage.

Through a geopolitical lens, it should be noted that Portuguese is the third most used European language in the southern hemisphere, according to data from the Instituto Camões (Camões Institute) and the Observatório da Língua Portuguesa (Portuguese Language Observatory). ${ }^{8}$ Taking into account the growing importance of Portuguese-speaking countries on the economic and demographic potential as well as in the access to raw materials and increasingly scarce goods (such as drinking water and arable surface), as Carlos Lopes and João Gomes Cravinho highlighted in their analysis of the Angolan and Brazilian cases, respectively, the possibility of a wider dissemination of the Portuguese language in regional and continental contexts becomes more plausible. This expansion will naturally be limited by the maintenance of the status of global lingua franca occupied by the English language. However, as Radha Kumar pointed out, the search for new forms of international relationships marked by the South-South cooperation will become a clear future trend, and in this regard the "symbolic capital" of the Portuguese language can be superior to that of the other European languages, due to the large influence of Brazil as an economic centre and cultural promoter.

As to the dissemination of the Portuguese language in European context, the economic crisis Portugal has been facing in recent years seems to have affected the public investment in language programmes and policies. The scarce resources are a limiting factor that impairs the maintenance and foundation of other Camões Institutes or Portuguese schools, and hinders investment in the educational offer at a higher level, which invariably includes sponsoring chairs or lecturers, while it decreases the impact of financed programmes for the promotion and teaching of Portuguese as a foreign language, both in Portugal and in Europe. However, when comparing the language policies of such international cultural and linguistic bodies as the Organisation Internationale de la Francophonie or the Commonwealth of Nations with those

\footnotetext{
${ }^{7}$ Portuguese Speaking Internet Users Statistics. Internet User Statistics and Population Stats for the countries and regions with Portuguese Speaking Internet Users. Available at: http://www.internetworldstats.com/stats20.htm.

${ }_{8}$ For more information, please see: http://observalinguaportuguesa.org/category/dadosestatisticos/graficos/page/2/.
} 
implemented by Portuguese-speaking countries, we quickly come to the conclusion that the greatest challenge posed to the responsible and consistent political management aware of the valuable linguistic heritage that is the Portuguese language is mostly a symbolic and conceptual one. In the present polycentric context, being a language community not relying on common identity notions but able to handle a multipolar management of its linguistic heritage can prove to be an advantage.

\section{Summary}

In the lively and passionate discussion - an inter and pluri-disciplinary one promoted within the scope of the Serralves conferences, some polycentrist trends were identified. First of all, it was generally agreed throughout the several sessions that globalisation has promoted concurrent fragmentation and integration trends, in the face of an increasingly interdependent international system at the economic, financial, cultural, and technological levels, although it also lacks a global order for this same globalisation. Secondly, polycentrism implies the coexistence of multiple centres of power, where average powers and regional arrangements may play a greater role, not involving, however, the elimination of hierarchies and differentials. This reconfiguration raises various questions about the position and contributions of the EU, as well as Portugal's. Thirdly, the mechanisms of global governance, including cultural and language issues, may enable a different projection of power while providing new dimensionality to certain matters not always considered a priority in the agenda.

The uncertainty that defines the international system is extensive to the very analysis of the different trends identified. However, and paraphrasing Barroso, as he quoted U2's lead singer in the band's album 'Zooropa':

Don't worry baby, it's gonna be alright

Uncertainty... can be a guiding light.

Article received on November 15, 2016 | Accepted November 30, 2016 